\title{
Pemodelan Faktor-faktor yang Mempengaruhi Angka Kematian Ibu di Jawa Timur Menggunakan Geographically Weighted Regression
}

\author{
Ilalang Akar Pertiwi'1, Nurul Kholisatin', Naziehah Taibatunniswah', \\ Achmad Choiruddin ${ }^{1^{\star}}$, dan Sutikno ${ }^{1}$ \\ ${ }^{1}$ Departemen Statistika, Fakultas Sains dan Analitika Data, Institut Teknologi Sepuluh Nopember \\ *Corresponding author: choiruddin@its.ac.id
}

\begin{abstract}
Received: 15 March 2021 Accepted: 27 March 2021 Published: 31 March 2021
\end{abstract}

\begin{abstract}
Angka Kematian Ibu (AKI) merupakan jumlah kematian ibu di setiap 100 kelahiran bayi hidup. Kematian ibu menjadi salah satu indikator dalam menggambarkan kesejahteraan masyarakat di suatu negara. Kematian ibu juga menjadi salah satu parameter terkait derajat kesehatan perempuan. Jumlah kematian ibu dihitung dari kematian selama masa kehamilan, persalinan, dan nifas atau pengelolaannya, bukan dihitung dari sebab-sebab lainnya seperti kecelakaan atau jatuh. Banyak faktor yang dapat menyebabkan kematian ibu diantaranya, kunjungan ibu hamil antenatal, riwayat komplikasi, kekurangan darah, persalinan di fasilitas pelayanan kesehatan, tenaga kesehatann terlatih, dan lain-lain. Dalam analisis ini akan dilakukan pemodelan statistika untuk mengetahui faktor-faktor penyebab tingginya persentase kematian ibu di Jawa Timur dengan menggunakan regresi linier dan juga pemodelan spasial. Terdapat delapan variabel prediktor yang masing-masing karakteristiknya berbeda satu dengan yang lain. Berdasarkan kebaikan modelnya, metode OLS adalah metode paling baik yang dapat menggambarkan kasus tingginya angka kematian ibu di Jawa Timur dengan baik.
\end{abstract}

Keywords- AKI, Jawa Timur, OLS, Regresi, Spasial

\section{PENDAHULUAN}

Angka kematian ibu (AKI) merupakan jumlah kematian ibu di setiap 100 kelahiran bayi hidup. Berdasarkan Survey Demografi dan Kesehatan Indonesia (SDKI), pada tahun 1994 sampai dengan 2007 telah terjadi penurunan angka kematian ibu di Indonesia, yaitu 0,390 menjadi 0,228 per 100 kelahiran bayi hidup. Namun, pada tahun 2012 menunjukkan adanya peningkatan angka kematian ibu yang signifikan menjadi 0,359 per 100 kelahiran bayi hidup. Sedangkan, menurut hasil Survey Penduduk Antar Sensus (SUPAS) 2015, angka kematian ibu mengalami penurunan kembali menjadi 0,305 kematian ibu per 100 kelahiran bayi hidup. Selain itu, salah satu tujuan dari SDGs adalah tercapainya angka kematian ibu pada tahun 2030 sebesar 0,070 per 100 kelahiran bayi hidup[1]. Pada tahun 2013, Provinsi Jawa Barat menduduki peringkat tertinggi dalam angka kematian ibu yaitu sebanyak 765 kasus dari total 5.019 kasus. Provinsi Jawa Tengah dan Jawa Timur menduduki peringkat tertinggi selanjutnya yaitu sebanyak 668 dan 642 kasus [2].

Banyak faktor yang dapat menyebabkan kematian ibu diantaranya, kunjungan ibu hamil antenatal, riwayat komplikasi, kekurangan darah, persalinan di fasilitas pelayanan kesehatan, tenaga kesehatan terlatih, dan lain-lain [3]. Persentase kematian ibu di Jawa Timur merupakan data persentase sehingga metode statistik yang tepat digunakan adalah regresi poisson. Namun, karena data yang digunakan adalah data tiap kabupaten / kota di Jawa Timur dimana terdapat daerah yang rawan terhadap kematian ibu yaitu di daerah tapal kuda[4] sehingga memungkinkan asumsi hemoskedastisitas tidak terpenuhi pada regresi global, maka diperlukan metode pemodelan yang memperhitungkan faktor lokasi / spasial.

\section{METODOLOGI PENELITIAN}

\begin{tabular}{cl}
\multicolumn{1}{c}{ Tabel 1. Variabel Penelitian } \\
\hline Variabel & \multicolumn{1}{c}{ Keterangan } \\
\hline $\mathrm{Y}$ & Angka Kematian Ibu tiap Kabupaten / Kota \\
$\mathrm{X}_{1}$ & Persentase Rumah tangga ber-PHBS tiap Kabupaten / Kota \\
$\mathrm{X}_{2}$ & Persentase Penanganan Komplikasi Kebidanan tiap Kabupaten / Kota \\
$\mathrm{X}_{3}$ & Persentase Kunjungan Ibu Hamil (K4) tiap Kabupaten / Kota \\
$\mathrm{X}_{4}$ & Persentase Rumah Tangga Menerima Bantuan Tunai tiap Kabupaten / Kota \\
$\mathrm{X}_{5}$ & Rasio Puskesmas dan Rumah Sakit tiap Kabupaten / Kota \\
$\mathrm{U}$ & Koordinat Lintang Kabupaten / Kota \\
$\mathrm{V}$ & Koordinat Bujur Kabupaten / Kota \\
\hline
\end{tabular}

\section{A. Sumber Data}

Data yang digunakan dalam penelitian ini berasal dari data sekunder, yaitu data yang berasal dari Profil Kesehatan Provinsi Jawa Timur 2016 yang dipublikasikan oleh Dinas Kesehatan Jawa Timur serta terdapat data sekunder yang berasal dari Badan Pusat Statistik. Unit penelitian yang diteliti yaitu kabupaten/kota di Jawa Timur. 


\section{B. Variabel Penelitian}

Variabel penelitian yang digunakan dalam praktikum ini disajikan pada Tabe1.

\section{Langkah-Langkah Penelitian}

Langkah analisis yang digunakan pada penelitian pada penelitian ini adalah sebagai berikut.

1. Mengumpulkan data.

2. Melakukan analisis statistika deskriptif tiap variabel.

3. Melakukan analisis korelasi antar variabel.

4. Melakukan uji multikolinieritas variabel prediktor.

5. Melakukan uji parameter simultan dan parsial.

6. Membentuk regresi linier dengan metode OLS

7. Melakukan uji dependensi dan heterogenitas spasial.

8. Menentukan bandwidth optimum.

9. Membentuk pemodelan spasial berdasarkan data.

10. Melakukan pemilihan model terbaik.

11. Menginterpretasikan hasil.

12. Menarik kesimpulan dan saran.

\section{ANALISIS DAN PEMBAHASAN}

\section{A. Karakteristik Angka Kematian Ibu per Jumlah Kelahiran Bayi Hidup dan Faktor-Faktor yang} Mempengaruhinya

Karakteristik faktor-faktor yang diduga mempengaruhi jumlah kematian ibu di Jawa Timur disajikan pada Tabel 1 berikut ini.

Tabel 2. Statistika Deskriptif

\begin{tabular}{ccccc}
\hline Variabel & Mean & St.dev & Minimum & Maksimum \\
\hline $\mathrm{Y}$ & 0,09986247 & 0,04281321 & 0,03837299 & 0,2361833 \\
$\mathrm{X}_{1}$ & 49,64 & 14,78 & 19,4 & 75,1 \\
$\mathrm{X}_{2}$ & 96,03 & 15,44 & 62,1 & 129,5 \\
$\mathrm{X}_{3}$ & 88,858 & 5,045 & 78,9 & 98,5 \\
$\mathrm{X}_{4}$ & 2,342 & 2,474 & 0 & 11,78 \\
$\mathrm{X}_{5}$ & 7,813 & 3,035 & 4,53 & 18,69 \\
\hline
\end{tabular}

Analisis secara deskriptif dilakukan untuk mendapatkan karakteristik persentase kematian ibu per jumlah kelahiran bayi hidup (Y) dan faktor-faktor yang mempengaruhinya. Pada tahun 2016, jumlah kematian ibu di Provinsi Jawa Timur sebanyak 534 jiwa. Berdasarkan Tabel 1, persentase kematian tertinggi yaitu sebanyak 0,236\%, dengan rata-rata tiap kabupaten/kota sebesar 0,09986247\%.

\section{B. Pola Hubungan Jumlah Kematian Ibu dengan Faktor-faktor yang Mempengaruhi}

Untuk melihat adanya hubungan antara jumlah kematian ibu dengan faktor-faktor yang diduga mempengaruhinya, tidak hanya melihat dari nilai-nilai karakteristik yang didapatkan namun juga diperlukan adanya analisis korelasi. Berikut merupakan visualisasi dari analisis korelasi antara jumlah kematian ibu dengan setiap faktor yang diduga mempengaruhinya.

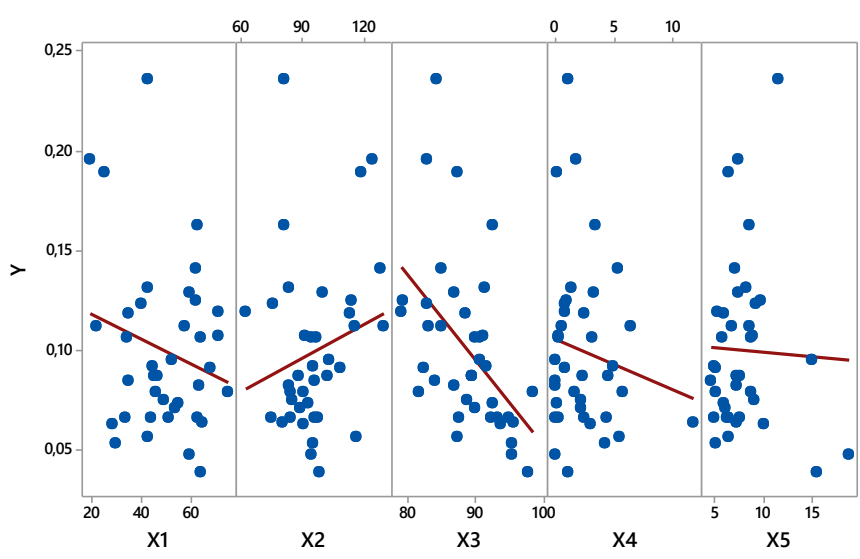

Gambar 1. Scatter Plot Variabel Prediktor vs Variabel Respon 
Gambar 1 menunjukkan bahwa variabel prediktor rasio puskesmas dan rumah sakit $\left(\mathrm{X}_{5}\right)$ cenderung tidak memiliki hubungan atau korelasi yang signifikan dengan variabel respons persentase kematian ibu (Y). Sementara variabel persentase rumah tangga ber-PHBS $\left(\mathrm{X}_{1}\right)$, persentase penanganan komplikasi kebidanan $\left(\mathrm{X}_{2}\right)$, persentase kunjungan ibu hamil $\left(X_{3}\right)$, dan persentase rumah tangga menerima bantuan tunai $\left(X_{4}\right)$ memiliki hubungan korelasi yang negatif terhadap variabel respons persentase kematian ibu per jumlah kelahiran bayi hidup (Y).

\section{Persebaran Data Angka Kematian Ibu per Jumlah Kelahiran Bayi dan Faktor-faktor yang Mempengaruhi di Provinsi Jawa Timur}

Setelah diketahui adanya hubungan antara jumlah kematian ibu dengan faktor-faktor yang diduga mempengaruhinya, dilakukan analisis persebaran untuk setiap variabel prediktor terhadap persentase kematian ibu per jumlah kelahiran bayi hidup di Jawa Timur sebagai berikut.

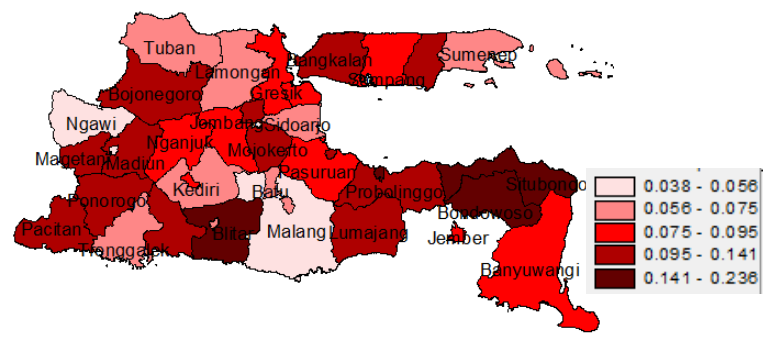

Gambar 2. Persebaran Angka Kematian Ibu Tiap 100 Kelahiran Bayi Hidup di Jawa Timur

Berdasarkan Gambar 2. Terdapat 3 kabupaten yang memiliki angka kematian ibu yang sangat kecil. Namun,demikian terdapat pula kabupaten / kota yang memiliki nilai persentase kematian ibu yang tinggi yakni di kabupaten Situbondo, Bondowoso, dan Blitar.

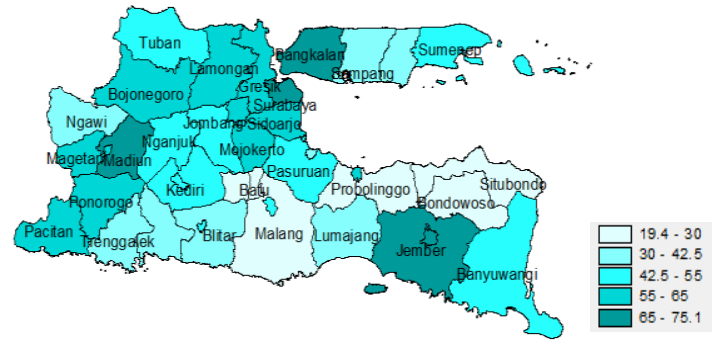

Gambar 3. Persebaran Persentase Rumah Tangga-PHBS

Berdasarkan Gambar 3. Terdapat 4 Kabupaten / Kota yang memiliki persentase rumah tangga ber-PHBS 19,4\% 30\% yakni Kabupaten Malang, Kabupaten Probolinggo, Kabupaten Situbondo, dan Kabupaten Bondowoso. 34 Kabupaten / Kota yang lain memiliki persentase rumah tangga ber-PHBS diatas $30 \%$ dimana 4 diantaranya persentase rumah tangga yang-PHBS mencapai $65 \%$ - 75,1\%. Selanjutnya variabel persentase penanganan komplikasi kebidanan disajikan pada Gambar 4.

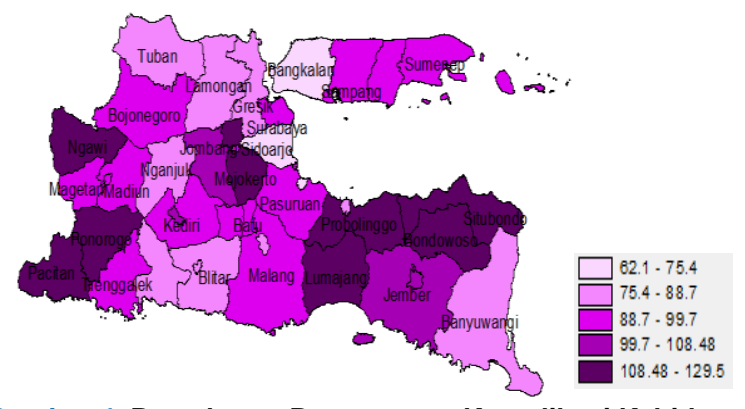

Gambar 4. Persebaran Penanganan Komplikasi Kebidanan

Gambar 4 Menunjukkan bahwa lebih dari 50\% Kabupaten / Kota di Jawa Timur telah memiliki persentase penanganan komplikasi kebidanan lebih dari 88,7\%. Nilai terkecil untuk persentase penanganan komplikasi kebidanan adalah $62,1 \%$ - 75,4\% yang masih terdapat pada 2 daerah di Jawa Timur. Selanjutnya variabel persentase kunjungan ibu hamil (K4) disajikan pada Gambar 5. 


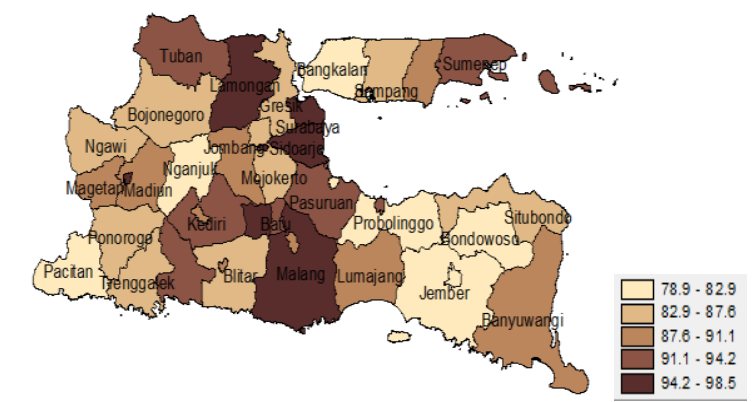

Gambar 5. Persebaran Persentase Kunjungan Ibu Hamil (K4)

Berdasarkan Gambar 5 Persentase kunjungan ibu hamil (K4) yang tinggi tidak lebih dari setengah wilayah Jawa Timur, dan kebanyakan berada pada daerah yang terletak di bagian tengah Provinsi. Daerah tapal kuda (Probolinggo, Lumajang, Pasuruan, Jember, Situbondo, Bondowoso dan Banyuwangi) mayoritas memiliki nilai persentase yang rendah antara $78,9 \%-87,6 \%$. Selanjutnya variabel persentase rumah tangga menerima bantuan tunai disajikan ada Gambar 6 .

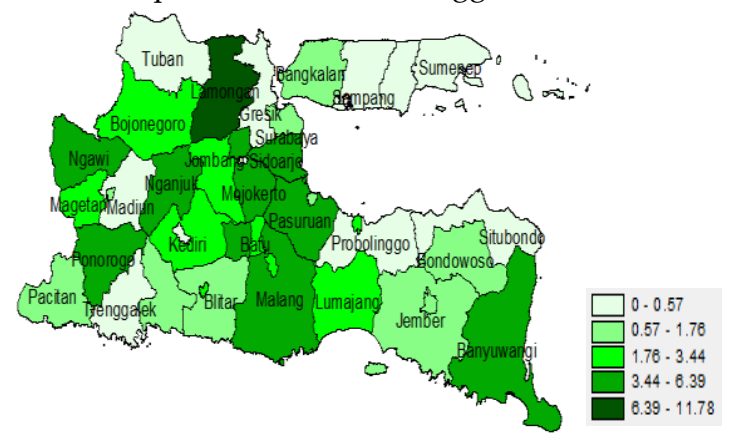

Gambar 6. Persebaran Persentase Rumah Tangga Menerima Bantuan Tunai

Gambar 6 Menunjukkan bahwa Kabupaten / Kota dengan persentase rumah tangga menerima bantuan tunai paling tinggi sebesar 6,39\% - 11,78\% hanyalah Kabupaten Lamongan. Kemudian untuk persentase tertinggi kedua 3,44\% 6,39\% digambarkan dengan warna hijau yang agak tua memiliki anggota Kabupaten / Kota terbanyak. Persentase terkecil $0 \%-0,57 \%$ digambarkan dengan warna putih juga terdapat pada 9 Kabupaten / Kota. Sisanya adalah Kabupaten / Kota dengan presentase sekitar 0,57-3,44\%. Selanjutnya, untuk persebaran variabel terakhir, persentase rasio puskesmas dan rumah sakit disajikan pada Gambar 7.

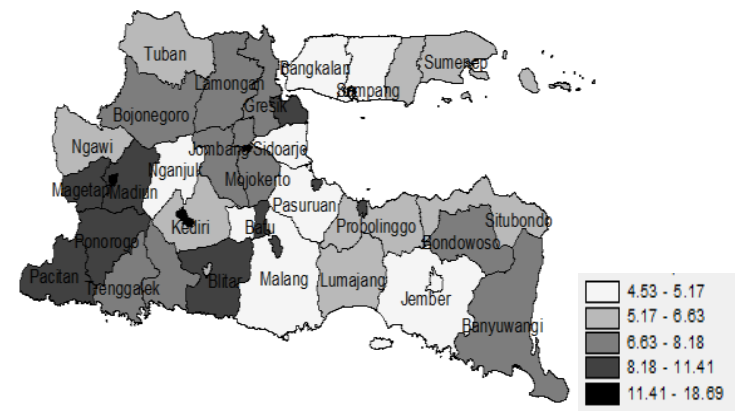

Gambar 7. Persebaran Rasio Puskesmas dan Rumah Sakit

Berdasarkan Gambar 7 dapat dilihat bahwa sebagian besar wilayah di Jawa Timur belum memiliki rasio puskesmas dan rumah sakit untuk setiap 100.000 penduduk wanita yang memadai. Nilai paling tinggi terdapat pada Kota Mojokerto sebesar 18,69\% Kota Madiun sebesar 15,43\% dan Kota Kediri sebesar 14,84\%.

\section{Pengujian Multikolinearitas}

Pengujian multikolinieritas dilakukan untuk mengetahui apakah model regresi yang didapatkan menunjukkan adanya hubungan antar variabel bebas (independen).

\begin{tabular}{cc}
\multicolumn{2}{c}{ Tabel 3. Nilai VIF } \\
\hline Variabel & VIF \\
\hline X1 & 1,2494 \\
X2 & 1,2297 \\
X3 & 1,2480 \\
X4 & 1,1759 \\
X5 & 1,2826 \\
\hline
\end{tabular}

Tabel 3 menunjukkan bahwa nilai Variance Inflation Factor (VIF) dari setiap variabel memiliki nilai lebih kecil dari 10. Hal ini berarti bahwa model regresi yang didapatkan tidak memiliki hubungan antar variabel atau tidak terjadi gejala multikolinieritas sehingga dapat dikatakan bahwa model regresi yang didapatkan adalah baik. 


\section{E. Pemodelan Regresi Linear Berganda}

Berikut merupakan hasil estimasi parameter dari model regresi yang didapatkan.

Tabel 4. Estimator Model Regresi

\begin{tabular}{cc}
\hline Parameter & Coefficient \\
\hline$\hat{\beta}_{0}$ & 0,4775 \\
$\hat{\beta}_{1}$ & $-0,0003896$ \\
$\hat{\beta}_{2}$ & 0,00007274 \\
$\hat{\beta}_{3}$ & $-0,004265$ \\
$\hat{\beta}_{4}$ & $-0,0003484$ \\
$\hat{\beta}_{5}$ & 0,001865 \\
\hline
\end{tabular}

Informasi yang terkandung dalam Tabel 4 dapat digunakan untuk pengujian selanjutnya yakni uji parameter simultan atau serentak (Exact Fisher Test) dan uji parameter parsial (Student's T Test). Berikut merupakan hasil pengujian parameter simultan atau serentak yang dicantumkan dalam Tabel 5.

Tabel 5. Uji Parameter Simultan

\begin{tabular}{ccc}
\hline Source & F-Value & P-Value \\
\hline Regression & 2,539 & 0,04808 \\
\hline
\end{tabular}

Tabel 5 menunjukkan bahwa nilai P yang didapat lebih kecil dibandingkan $\alpha$ sebesar $5 \%$ artinya semua variabel bebas (independen) berpengaruh signifikan terhadap model. Hal ini memberi keputusan yakni tolak $\mathrm{H}_{0}$ yang mana berarti minimal terdapat satu variabel yang berpengaruh signifikan terhadap model. Untuk melihat lebih lanjut variabel bebas (independen) mana yang memberikan pengaruh signifikan terhadap variabel terikat (dependen), dilakukan pengujian lanjutan yakni uji parameter parsial seperti yang dicantumkan pada Tabel 6 berikut ini.

\begin{tabular}{cc}
\multicolumn{2}{c}{ Tabel 6. Uji Parameter Parsial } \\
\hline Source & $p$-value \\
\hline Constant & $0,00193^{* *}$ \\
X1 & 0,42706 \\
X2 & 0,87536 \\
X3 & $0,00509^{* *}$ \\
X4 & 0,90201 \\
X5 & 0,44086 \\
\hline
\end{tabular}

Tabel 6 tersebut memberikan informasi bahwa nilai $p$-value pada konstan dan variabel $\mathrm{X}_{3}$ lebih kecil dibandingkan dengan alpha $5 \%$ sehingga kesimpulan yang didapatkan yaitu tolak $H_{0}$. Hal ini berarti konstan dan $X_{3}$ memberikan pengaruh signifikan terhadap variabel terikat (dependen). Sedangkan variabel $\mathrm{X}_{1}, \mathrm{X}_{2}, \mathrm{X}_{4}$ dan $\mathrm{X}_{5}$ menghasilkan nilai $p$ value yang lebih besar daripada alpha $5 \%$, maka gagal tolak $\mathrm{H}_{0}$ sehingga keempat variabel tersebut tidak memberikan pengaruh signifikan terhadap variabel terikat (dependen).

\section{F. Pengujian aspek spasial}

Pengujian aspek spasial dilakukan dengan menggunnakan uji Breusch-Pagan untuk menguji heterogenitas spasial, sedangkan uji Moran's I digunakan untuk menguji Dependensi Spasial.

Hipotesis untuk uji Breusch-Pagan yaitu sebagai berikut.

$\mathrm{H}_{0}$ : Tidak terjadi heterogonitas

$\mathrm{H}_{1}$ : Terjadi heterogenitas

Sementara hhipotesis untuk uji Moran's I yaitu sebagai berikut.

$\mathrm{H}_{0}$ : Tidak terjadi dependensi spasial

$\mathrm{H}_{1}$ : Terjadi dependensi spasial

Hasil pengujian spasial disajikan dalam tabel di bawah ini.

\begin{tabular}{ccc}
\multicolumn{3}{c}{ Tabel 7. Uji Efek Spasial } \\
\hline Pengujian & Nilai & P-Value \\
\hline Breusch-Pagan & 5,8606 & 0,32 \\
Moran's I & $-0,01218783$ & 0,6141212 \\
\hline
\end{tabular}

Berdasarkan tabel 7. Uji heterogenitas untuk data mengasilkan $p$-value yang kurang dari alpha sehingga tidak terdapat efek heterogenitas pada data. Kemudian untuk uji dependensi juga gagal tolak yang berarti tidak terdapat dependensi antar lokasi. Namun, untuk selanjutnya akan tetap diasumsikan menggunakan heterogenitas karena mempertimbangkan p-value Breusch-Pagan yang lebih kecil dibandingkan dengan hasil p-value pada Moran's I.

\section{G. Pemodelan GWR}

Tahap awal dalam pembentukan model GWR adalah dengan menetapkan lokasi pengamatan berdasarkan letak geografis linta dan bujur setiap kabupaten/kota. Kemudian mencari jarak Euclidean yang digunakan untuk menentukan bandwidth optimum dengan kriteria AIC paling minimum. Fungsi kernel yang akan digunakan untuk menentukan 
bandwidth optimum dipilih dari empat fungsi kernel meliputi Fixed gaussian, Fixed Bisquare, Adaptive Gaussian, dan Adaptive Bisquare. Berikut merupakan nilai AIC yang diperoleh dari keempat fungsi kernel tersebut.

\begin{tabular}{cc} 
Tabel 8. Pemilihan Bandwidth Optimum \\
\hline Fungsi Kernel & Nilai AIC \\
\hline Fixed Gaussian & $-142,2829$ \\
Fixed Bisquare & $-140,0107$ \\
Adaptive Gaussian & $-145,9601$ \\
Adaptive Bisquare & $-144,399$ \\
\hline
\end{tabular}

Berdasarkan Tabel 8. Nilai AIC yang terkecil diperoleh pada fungsi kernel menggunakan Adaptive Gaussian dengan nilai bandwidth optimum sebesar 0,842119.

\section{H. Pengujian Kesesuaian Model Regresi Linear Berganda dengan Model GWR}

Pengujian kesesuaian model digunakan untuk menjelaskan apakah model GWR dapat menjelaskan lebih baik dibandingkan denngan model regresi linear atau tidak. Hipotesi yang digunakan yaitu sebagai berikut.

$H_{0}: \beta_{k}\left(u_{i}, v_{i}\right)=\beta_{k}$

$H_{0}: \beta_{k}\left(u_{i}, v_{i}\right) \neq \beta_{k}$

Berikut merupakan tabel ANOVA pengujian kesesuaian model.

\begin{tabular}{ccccc}
\multicolumn{5}{c}{ Tabel 9. Kesesuaian Model } \\
\hline Model & df & SSE & F-value & P-value \\
\hline GWR & 32 & 0,0485527 & 1,3488 & 0,2241 \\
OLS & 24,535 & 0,03599756 & &
\end{tabular}

Berdasarkan Tabel 9. Nilai p-value pada model GWR menghasilkan keputusan gagal tolak $\mathrm{H}_{0}$ yang berarti model yang dihasilkan tidak leih baik djika dibandingkan dengan OLS. Namun, selanjutnya analisis masih akan dilanjutkan menggunakan model GWR untuk mengetahui model terbaiknya.

\section{Penentuan dengan Model GWR}

Pengujian kesesuaian model digunakan untuk menjelaskan apakah model GWR dapat menjelaskan lebih baik dibandingkan denngan model regresi linear atau tidak. Hipotesi yang digunakan yaitu sebagai berikut.

Penentuan model GWR ini menggunakan fungsi kernel Adaptive Gaussian. Kemudian akan didapatkan estimasi parameter yang berbeda tiap kabupaten/kota.

Berikut merupakan pengelompokkan kabupaten/kota di Jawa Timur berdasarkan variabel yang signifikan dengan taraf signifikansi sebesar $25 \%$.

Tabel 10. Daftar Kabupaten Dengan Variabel yang Signifikan

\begin{tabular}{cl}
\hline Variabel Signifikan & \multicolumn{1}{c}{ Kabupaten/kota } \\
\hline$X_{3}$ & Bangkalan, Kota Batu, Blitaar, Kota Blitar, Bojonegoro, Bondowoso, \\
& Gresik, Jember, Jombang, Kediri, Kota Kediri, Lamongan, Lumajang, \\
& Madiun, Kota Madiun, Magetan, Malang, Kota Malang, Mojokerto, \\
& Kota Mojokerto, Nganjuk, Ngawi, Pamekasan, Pasuruan, Kota \\
& Pasuruan, Ponorogo, Probolinggo, Kota Probolinggo, Sampang, \\
& Sidoarjo, Sumenep, Kota Surabaya, Trenggalek, Tuban, \\
& Tulungagung \\
\hline$X_{5}$ & Banyuwangi \\
\hline$X_{2}, X_{3}$ & Pacitan \\
\hline- & Situbondo
\end{tabular}

Tabel di atas menunjukkan bahwa variabel $X_{5}$ merupakan variabel yang signifikan dalam mempengaruhi angka kematian ibu tiap 100 kelahiran bayi hidup di Kabupaten Banyuwangi. Variabel $X_{2}$ dan $X_{3}$ merupakan variabel yang signifikan dalam mempengaruhi angka kematian ibu tiap 100 kelahiran bayi hidup di Kabupaten Pacitan. Sementara variabel $\mathrm{X}_{3}$ merupakan variabel yang signifikan dalam mempengaruhi angka kematian ibu per jumlah kelahiran bayi hidup di seluruh kabupaten/kota di Jawa Timur kecuali Kabupaten Banyuwangi, Pacitan, dan Bondowoso.

Contoh model untuk Kabupaten Pacitan adalah sebagai berikut,

Dimana,

$$
\hat{y}=0,670628-0,00111 x_{2}-0,00574 x_{3}
$$

$\hat{y}$ : Angka Kematian Ibu tiap kelahiran 100 bayi hidup.

$x_{2}$ : Persentase Penanganan Komplikasi Kebidanan tiap Kabupaten / Kota

$x_{3}$ : Persentase Kunjungan Ibu Hamil (K4) tiap Kabupaten / Kota 


\section{KESIMPULAN DAN SARAN}

Kesimpulan dalam penelitian yaitu persebaran angka kematian ibu tiap 100 kelahiran bayi hidup di Jawa Timur yang paling tinggi terdapat pada Kabuppaten Situbondo. Namun, hampir sebagian besar wilayah di jawa timur persentasenya tinggi. Untuk sebaran variabel lainnya kebanyakan daerah tapal kuda memiliki persentase yang lebih tinggi. Selanjutnya pengujian menggunakan uji multikolinieritas seluruh variabel memiliki nilai VIF dibawah 10 yang artinya tidak ada multikolinieritas pada variabel prediktor. Selanjutnya analisis menggunakan regresi linier berganda yang menghasilkan model dengan keseluruhan variabel prediktor yang signifikan terhadap model. Pengujian aspek spasial terhadap data mengahasilkan gagal tolak Ho untuk uji morans'I maupun breusch pagan. Sehingga, heterogenitas lebih dipertimbangkan dari pada dependensi karena nilai p-valuenya yang lebih kecil. Pemodelan menggunakan fungsi kernel yang paling optimum adalah menggunakan Adaptive Gaussian dengan bandwidth optimum sebesar 0,842119. Melalui pengujian kesesuaian model, model GWR ternyata tidak lebih bagus dibandingkan OLS. Terakhir penentuan model GWR seperti pada Tabel 10.

Saran bagi pemerintah masing-masing daerah adalah dapat meningkatkan tata letak kota serta dengan mempertimbangkan variabel-variabel yang signifikan pada model tiap daerah sehingga dapat menurunkan angka kematian ibu. Untuk penelitian selanjutnya, dapat dilakukan pengujian terlebih dahulu terkait efek spasial setiap variabel untuk menanggulangi adanya efek spasial yang tidak sesuai. Selain itu, pemodelan memperhatikan efek spasial dan temporal [5] dapat dipertimbangkan sebagai penelitian lanjutan.

\section{REFERENSI}

[1] Databoks, "Angka Kematian Ibu Turun Menjadi 305," 2017. [Online]. Available: https://databoks.katadata.co.id/. [Accessed 16 Desember 2019].

[2] Kompas, "Angka Kematian Ibu Tertinggi ada di Jawa Barat," 2014. [Online]. Available: https//sains.kompas.com. [Accessed 16 Desember 2019].

[3] Kemkes, "Peraturan Menteri Kesehatan Republik Indonesia Nomor 97 Tahun 2014," 2016. [Online]. Available: https://kesga.kemkes.go.id/. [Accessed 16 Desember 2019].

[4] Wahyu, Rawan Kematian Ibu Hamil di Tapal Kuda, Surabaya: Berita Metro, 2017.

[5] A. Choiruddin, Pemodelan Indikator Pencemar Biological Oxygen Demand di Kali Surabaya Menggunakan Pendekatan Spatial-Temporal Weighted Regression, Surabaya: Institut Teknologi Sepuluh Nopember, 2013. 